\title{
QR Codes Utilization in EFL Classroom: Affective Language
} Learning Attributes in Writing

\author{
Christopher Molingit Balintag ${ }^{1}$, Jeffrey Dawala Wilang \\ King Mongkut's University of Technology Thonburi, Thailand \\ Correspondence email: christopher.balin@mail.kmutt.ac.th
}

\section{Background:}

Abstract

Numerous positive gains have been reported on the use of technology in language learning. The current survey of published journal articles reveals a lack of research on its integration to language teaching and learning in graduate language classrooms in EFL settings. In this study, the use of QR codes in the graduate EFL classroom has been investigated concerning its relatedness to affective language learning attributes (herein referred to as ALLAs) including anxiety, engagement, motivation, self-esteem, among others during the lesson on the process of writing. Three objectives were sought (1) to know students' perceptions on ALLAs before and after the use of QR codes, (2) to establish the relationship between students' perceived ALLAs and language performance, and (3) to understand specific situations that trigger positive or negative reactions.

\section{Methodology:}

The students were asked to indicate their perceptions concerning ALLAs by using a survey questionnaire before and after the activity. They were also asked to do the QR codes activity to create an essay outline. Further, an open-ended questionnaire was provided to indicate their negative or positive reactions to specific situations during the QR-coded activity.

Findings:

Results suggest the following (1) there are significant differences in the students' perceived ALLAs before and after the activity, (2), there is a significant positive correlation between ALLAs and language performance, and (3) twelve specific situations were found to provoke dynamic ALLAs reactions.

\section{Conclusion:}

It is suggested that the use of available technological innovations must be introduced to graduate language teachers as its impacts on ALLAs are overwhelmingly beneficial.

Keywords: affective language learning attributes; QR Codes; graduate EFL classroom; technology

\begin{tabular}{|l|l|l|}
\hline DOI & $:$ & http://dx.doi.org/10.24903/sj.v5i1.425 \\
\hline Received & $:$ & February 2020 \\
\hline Accepted & $:$ & March 2020 \\
\hline Published & $:$ & April 2020 \\
\hline Copyright Notice & $:$ & $\begin{array}{l}\text { Authors retain copyright and grant the journal right of first publication with the } \\
\text { work simultaneously licensed under a Creative Commons Attribution 4.0 } \\
\text { International License that allows others to share the work with an acknowledgement of }\end{array}$ \\
\hline $\begin{array}{l}\text { the work's authorship and initial publication in this journal. } \\
\text { CC (i) (O) }\end{array}$ \\
\hline
\end{tabular}




\section{INTRODUCTION}

Current survey of published articles in international refereed journals reveals lack of research concerning the integration of QR codes in English language teaching and learning in graduate EFL classroom. Though graduate students have high levels of motivation, interest, concentration, in this paper, we argue that technology-driven activities for graduate EFL classes, specifically, the use of QR code in writing provokes higher levels of affective language learning attributes (or ALLAs) and that this relationship plays a vital role on how they perform in class. Thus, three objectives are sought. First, to know the differences of affective language learning attributes in writing before and after the QR code activity. Second, to establish the relationship between affective language learning attributes and language performance. Lastly, to know the situations that provoke affective language learning attributes in writing. Knowing the affective outcomes of using QR codes in writing would help teachers design in class writing activities that help 'flourish' the learner's well-being.

\subsection{Affective variables in language learning}

Affect is defined broadly as "aspects of emotion, feeling, mood or attitude which can condition behavior and influence language learning" (Arnold \& Brown, 1999). Hence, in the current study, ALLAs include but not limited to variables such as interest, motivation, concentration, self-esteem, comfortableness, anxiety, engagement, happiness, and relaxation.

It can be deduced from previous studies that technology-driven language activities influenced positive affective variables in language learning. Among Japanese undergraduate students, (Rivers, 2009) reported that majority of the participants agreed that the use of QR code was helpful because of its ease of use. Despite technological issues, students described QR code aided language activities as "fun, unusual, and interesting" (p. 26). Among Turkish students, the use of QR code has encouraging effects on language learning due to the use visuals, convenience, attractiveness, among others (Durak, Ozkeskin, \& Ataiza, 2016). Other affective variables generated on the use of QR code include higher levels of motivation and enjoyment, longer attention span, and lesser stress in language learning (Al-Khalifa, 2011; McCabe \& Tedesco, 2012; Situmoranga, Siangb, Ibrahimc, \& Lagunsiangd, 2019).

In language learning, previous studies further insinuated that language learners who possess the 'right' attitude can generate other affect, for example, motivation that could develop English language proficiency (Midraj, 2003). When students have poor attitude towards language learning, they become passive learners in the classroom (Gömleksiz, 2010). In other words, the higher level of motivation students' experiences in the classroom the better chance 
they can learn a new language (Saville-Troike, 2006). Henter (2014) found that motivation has a positive significant correlation with language performance. The same findings were reported among South Korean students (Lee \& Lo, 2017).

Anxiety has a negative effect on the students' language performance. In fact, several scholars such as Horwitz (2001) and MacIntyre \& Gardner (1989) noted that anxious students may feel less competent, unable to share ideas due to fear of making mistakes, afraid of being evaluated, among others. So language teachers are encouraged to raise students' motivation and decrease anxiety in order to attain better results in language performances.

Generally, anxiety in the foreign language classroom is composed of communication apprehension, test anxiety, and fear of negative evaluation (E. K. Horwitz, Horwitz, \& Cope, 1986; Kalra \& Siribud, 2020; Yang, Chang, Hwang, \& Zou, 2020). In an engineering graduate EFL classroom in Thailand, Vo, Wilang, \& Samoilova (2017) revealed three high anxiety provoking situations in the classroom such as I keep thinking that other students are better at English than I am, It would bother me to take more English classes, and I would be nervous speaking with native speakers. To find out anxiety's effect on language performances, Vo, Wilang, \& Samoilova (2017) found negative significant relationships between anxiety and group discussion, anxiety and group presentation, and anxiety and final grade. Thus, anxious students perform negatively.

Convincing effects of positive or negative language learning variables onto language learning have been established. To further knowledge on the 'affect' of graduate students, lesser known affective language learning variables are also included such as happiness, interest, comfortableness, relaxation, concentration and engagement.

\section{METHODOLOGY}

To support the argument in the earlier part of the paper, a classroom action research was conducted by the teacher-researchers to seek answers (see Context of study), to improve their teaching and to share the findings to a larger audience.

\subsection{The context of the study}

The study was conducted in a foundation writing course offered to graduate students in a reputable university in Thailand. The course is offered to graduate students of international programs who did not pass the required English language proficiency level. Only 25 students out of 32 from two classes participated and consented to take part in the data collection process. However, data collected from four students were excluded in the analysis due to missing responses in the survey. 
In the graduate writing class, the teacher-researcher usually provide paper-based activities to the students. Although the students were compliant to any given activity, it is supposed that their affective variables are not maximized. It is also possible that paper-based activities are boring, unengaging and non-stimulating.

\subsection{Affective language learning attributes or ALLAs}

Since there was no survey questionnaire that is suitable to the context of the study, ALLAs were elicited qualitatively by individually interviewing two graduate students. In the initial phase of the study, the initial list of ALLAs were combined and redundant phrases or items were deleted. To establish validity of the survey questionnaire, the list of ALLAs was distributed to another foundation writing course offered to graduate students of normal programs. Only the language learning attributes similarly experienced by the participants were used in the survey. In the final study, the survey was administered before the QR code activity and was found to be highly reliable at Cronbach's alpha .913. The survey is designed as a binary Likert scale from 7 (highest) to 1 (lowest).

The use of ' $n o$ ', 'not', or 'don' $t$ ' to negate the positive affect were easier for the students to comprehend. In addition, ' $I$ ' was utilized to personalize the statements so that it would be easier for the students to relate the items with their own experiences (see Table 1). The survey was administered twice - before and after the writing activity to know the differences of the students' affect.

\begin{tabular}{lcl} 
Table 1. ALLAs survey & \\
\hline Positive attributes & Level & Negative attributes \\
\hline I am extremely interested. & 7654321 & I am not interested. \\
I am extremely motivated. & 7654321 & I am not motivated. \\
I have extreme concentration. & 7654321 & I have no concentration. \\
I have extreme self-esteem. & 7654321 & I have no self-esteem. \\
I feel extremely comfortable. & 7654321 & I don't feel comfortable. \\
*I am extremely anxious. & 7654321 & I am not anxious. \\
I extremely engaged. & 7654321 & I am not engaged. \\
I am extremely happy. & 7654321 & I am not happy. \\
I feel extremely relax. & 7654321 & I don't feel relax. \\
\hline
\end{tabular}

*The scores were reverse-coded in the analysis.

The mean scores of ALLAs were interpreted accordingly. To know the range, the difference of the highest number, which is 7 , and the lowest number, which is 1 was calculated. Then the product, which is 6, was divided by 7. Accordingly, 6.15 to 7.00 means Extreme, 5.29 to 6.14 means Very high, 4.43 to 5.28 means High, 3.58 to 4.42 means Moderate, 2.72 to 3.57 means Low, 1.86 to 2.71 means Very low, and 1.00 to 1.85 means None. 


\subsection{QR code activity and language performance}

The $\mathrm{QR}$ code activity is an essay outline writing activity. Sixteen $\mathrm{QR}$ codes were printed in small sheets of paper and were posted around the classroom. The codes consisted of a thesis statement, three controlling ideas, and 12 supporting details - nine relevant and three irrelevant statements.

The students were given a blank paper to write their output. A sound thesis statement is marked 3 points, each controlling idea is marked 2 points, and each supporting details is marked 1 point. The scores were used to establish the relationship between ALLAs and language performance.

\subsection{Open-ended questionnaire}

After the QR code activity, the students were given an open-ended questionnaire and were asked to write specific situations that increase or decrease their affect. It is designed to understand the specific situations that trigger students' affect during the writing activity. For example, they were asked to encircle an option from very interesting or not interesting and identify the specific situation when it happened. Also, they were given an option to provide reason or reasons as they fit.

\subsection{Data analysis}

Because the study used a survey-dependent quantitative approach, descriptive and inferential statistics were used to compute the differences of affective language learning attributes before and after the QR code activity as well as the its relationship to language performance. The responses in the open-ended questionnaire were coded to provide opportunities to examine the classroom situations that provoke affective language learning variables such as interest, motivation, concentration, self-esteem, comfortableness, anxiety, engagement, happiness, and relaxation.

\section{FINDINGS}

This section presents the quantitative and qualitative results of the study.

\subsection{Affective language learning attributes before and after the activity}

Tables 2 and 3 reveal the answer to the first question - Are there differences in the affective language learning attributes in writing before and after the QR code activity?

Table 2. ALLAs before and after the activity

\begin{tabular}{ccccc}
\hline \multirow{2}{*}{ Affective language learning variables } & \multicolumn{2}{c}{ Before } & \multicolumn{2}{c}{ After } \\
\cline { 2 - 5 } & \multicolumn{2}{c}{$\mathbf{M , S D}$} & $\mathbf{M}, \mathbf{S D}$ \\
\hline I am extremely interested./ & $5.52,1.26$ & Very high & $6.05,0.84$ & Very high \\
I am not interested. & $5.21,0.91$ & High & $6.26,0.93$ & Extreme \\
I am extremely motivated./ & & &
\end{tabular}




\begin{tabular}{|c|c|c|c|c|}
\hline \multirow{3}{*}{$\begin{array}{l}\text { Affective language learning variables } \\
\text { I have extreme concentration./I have no } \\
\text { concentration }\end{array}$} & \multirow{2}{*}{\multicolumn{2}{|c|}{$\begin{array}{l}\text { Before } \\
M, S D\end{array}$}} & \multirow{2}{*}{\multicolumn{2}{|c|}{$\begin{array}{c}\text { After } \\
\text { M, } S D\end{array}$}} \\
\hline & & & & \\
\hline & $5.05,1.39$ & High & $5.84,0.83$ & Very high \\
\hline $\begin{array}{l}\text { I have extreme self-esteem./ } \\
\text { I have no self-esteem. }\end{array}$ & $4.78,1.31$ & High & $5.42,1.12$ & Very high \\
\hline $\begin{array}{l}\text { I feel extremely comfortable./ } \\
\text { I don't feel comfortable. }\end{array}$ & $4.73,1.09$ & High & $5.57,1.01$ & Very high \\
\hline $\begin{array}{c}\text { I am not anxious./ } \\
\text { I am extremely anxious. }\end{array}$ & $4.05,1.17$ & Moderate & $4.00,1.85$ & Moderate \\
\hline $\begin{array}{l}\text { I am extremely engaged./ } \\
\text { I am not engaged. }\end{array}$ & $5.52,1.54$ & Very high & $6.00,0.88$ & Very high \\
\hline $\begin{array}{l}\text { I am extremely happy./ } \\
\text { I am not happy. }\end{array}$ & $5.21,1.35$ & High & $5.94,0.91$ & Very high \\
\hline $\begin{array}{l}\text { I feel extremely relax./ } \\
\text { I don't feel relax. }\end{array}$ & $5.36,1.35$ & Very high & $6.15,1.01$ & Extreme \\
\hline
\end{tabular}

Based on descriptive statistics on table 2, six ALLAs changed respectively. For example, motivation moved up onto two notches from high to extreme levels. Also, concentration, self-esteem, comfortableness, happiness and relaxation increased for a notch, from high to very high or very high to extreme. Meanwhile, there ALLAs remained unchanged including interest, anxiety and engagement.

Table 3. Differences of ALLAs before and after the activity

\begin{tabular}{ll}
\multicolumn{1}{c}{ Affective language learning variables } & \multicolumn{1}{c}{$\boldsymbol{t}$-test } \\
\hline I am extremely interested./I am not interested. & $t(18)=2.53, p=.021$ \\
I am extremely motivated./I am not motivated. & $t(18)=7.38, p=.000$ \\
I have extreme concentration./I have no concentration & $t(18)=3.33, p=.004$ \\
I have extreme self-esteem./I have no self-esteem. & $t(18)=2.72, p=.014$ \\
I feel extremely comfortable./I don't feel comfortable. & $t(18)=2.91, p=.009$ \\
I am not anxious./I am extremely anxious. & $t(18)=0.14, p=.886$ \\
I am extremely engaged./I am not engaged. & $t(18)=1.58, p=.132$ \\
I am extremely happy./I am not happy. & $t(18)=2.92, p=.009$ \\
I feel extremely relax./I don't feel relax. & $t(18)=3.52, p=.002$ \\
\hline
\end{tabular}

Based on t-tests (see Table 3), there were no significant differences before and after the activity concerning anxiety $(\mathrm{M}=3.05, \mathrm{SD}=1.17 ; \mathrm{M}=3.00, \mathrm{SD}=1.85 ; t(18)=0.14, p=.886)$, and engagement $(\mathrm{M}=5.52, \mathrm{SD}=1.54 ; \mathrm{M}=6.00, \mathrm{SD}=0.85 ; t(18)=1.43, p=.168)$. These suggest the following: (1) the students remain anxious in the English class, and (2) the students' engagement toward English class did not necessarily change after the QR code activity was introduced.

Table 4. Summation of ALLAs before and after the activity

\begin{tabular}{|c|c|c|c|c|c|c|c|c|}
\hline \multirow{4}{*}{ Before/After } & \multicolumn{5}{|c|}{ Paired differences } & \multirow[b]{3}{*}{$\mathbf{t}$} & \multirow[b]{3}{*}{ df } & \multirow{3}{*}{$\begin{array}{l}\text { Sig. (2- } \\
\text { tailed) }\end{array}$} \\
\hline & \multirow[b]{2}{*}{ Mean } & \multirow{2}{*}{$\begin{array}{c}\text { Std. } \\
\text { Deviation }\end{array}$} & \multirow{2}{*}{$\begin{array}{l}\text { Std. } \\
\text { Error } \\
\text { Mean }\end{array}$} & \multicolumn{2}{|c|}{$\begin{array}{l}95 \% \text { Confidence } \\
\text { Interval of the } \\
\text { Difference }\end{array}$} & & & \\
\hline & & & & Lower & Upper & & & \\
\hline & -8.78 & 7.45 & 1.71 & -12.38 & -5.19 & -5.13 & 18 & .000 \\
\hline
\end{tabular}


Previously, descriptive analysis and t-tests yielded differing results so the summation of ALLAs before and after the activities was computed. Table 4 shows that there was a significant difference concerning the feelings or emotions of graduate students before $(\mathrm{M}=56.00, \mathrm{SD}=10.49)$ and after the $\mathrm{QR}$ code activity $(\mathrm{M}=64.78, \mathrm{SD}=6.67) ; t(18)=5.13, p=.000$. This result suggests that when the QR code activity was introduced during the writing lesson, most affect (except for interest, anxiety and engagement) have increased favorably (see above results in Table 2 and 3 ).

The above results need plausible explanations. The lower level of anxiety after the QR code activity, although non-significant, could be due to the students' high level of motivation, suitability of the activity and a 'very relaxing' class environment. Similar to anxiety, there was no significant change on the students' engagement before and after the activity. This could be due to the educational level of the students, who are first year master and doctoral students, and in their first semester of graduate studies. The educational background could also explain why the students have high affect. They needed to pass this course so they can concentrate on their research in the succeeding semesters.

It can also be concluded that the use of technology, as previously reported, also increases the feelings or emotions of students in the peripheral countries. Like Japanese students, students in Thailand reported affective language learning variables positively provoked by QR code activity including higher levels of interest, motivation, concentration, self-esteem, comfortableness, happiness, and relaxation (see Rivers, 2009).

Table 5 answers research question 2 - Is there a relationship between affective language learning attributes and language performance?

Table 5. Relationship of ALLAs and language performance

\begin{tabular}{lccc}
\hline & $\begin{array}{c}\text { ALLAs before } \\
\text { the activity }\end{array}$ & $\begin{array}{c}\text { ALLAs after the } \\
\text { activity }\end{array}$ & Performance scores \\
\hline ALLAs before the activity & - & $.708 * *$ & -
\end{tabular}

ALLAs after the activity - - - $\quad 618^{* *}$

** Correlation is significant at the 0.01 level

Similar to results in Table 4, the findings above (refer to Table 5) reveal that ALLAs before the QR code activity was significantly correlated with ALLAs after the activity ( $r=.718$, $p=.001$ ). This suggests that the feelings or emotions of the students before writing have increased after doing the QR code activity. As expected, ALLAs after the activity was significantly correlated with the students' scores $(\mathrm{r}=.618, p=.005)$. This means that positive feelings or emotions could be helpful in their writing performance. However, future research may design an experimental study to ascertain the current findings of this study. 


\subsection{Situations that provoked positive affective language learning attributes}

Following the data analysis, Table 6 reveals the categories and subcategories of affective language learning attributes related to the QR code activity in writing. The presentation of data helps to answer the last research question - What are the situations that provoke affective language learning attributes in writing?

Four categories of situations were coded included game-based, process of writing, technology and teacher related situations (see Table 6). These categories of situations contribute to positive ALLAs in a QR-coded graduate EFL classroom.

In the first category, game-based related situations include independent learning, collaborative learning, sense of pride, and environmental considerations. For independent learning, ALLAs include high engagement (i.e., I am engaged actively when I practice on my own), high self-esteem (i.e., I feel confident when I perform the activity independently), very happy (i.e., I feel very happy when I play game), very interested (i.e., I feel interested when I scan the code by myself), and very relaxing (i.e., I feel very relax when I scan codes as no one forces me). For collaborative learning, ALLAs include high engagement (for example, I am engaged actively when I play with the others), very happy (for example, I feel very happy when everyone do the activity), very interested (for example, I feel very interested when all students are doing it), and very relaxing (for example, I feel very relax when I talk with my classmates while doing the activity). For sense of pride, five ALLAs are high self-esteem (for instance, I have high self-esteem as I can do it by myself), very comfortable (for instance, I feel very comfortable when I found all the codes), very happy (for instance, I am very happy when I can read the text in the $Q R$ code), high motivation (for instance, I am very motivated when I can finish the task), and very relaxing (for instance, I feel very relax when I finished the job very fast). For environmental considerations, one affective variable, which is, very comfortable was coded. For example, I feel very comfortable when the environment is very friendly.

In the second category, process of writing related situations include amount of work, content of the activity, finding information, and analyzing the data. Amount of work provokes high concentration, for example, I have high concentration when I repeat writing the sentence. Content of the activity include high self-esteem - I feel very confident when I am familiar with what we are going to do, and happiness - I feel very happy when the content is funny. For finding information, ALLAs include high concentration - I have when I have to find the hidden text, very happy - Ifeel happy when I scan and the information appears, very interested - I am very interested when the I don't know what are in the codes, high motivation - I feel very 
motivated when I can find the information to complete my work. For analyzing data, it includes high concentration - I have high concentration when I found the data and think on how to link the sentences together, and high motivation - I very motivated when it has a lot of information to process.

Table 6. Categories and subcategories

\begin{tabular}{|c|c|c|c|}
\hline \multirow[t]{2}{*}{ Main categories } & \multirow[t]{2}{*}{ Subcategories } & \multicolumn{2}{|l|}{ Affective attributes } \\
\hline & & High & Low \\
\hline \multirow[t]{4}{*}{$\begin{array}{l}\text { Game-based } \\
\text { related situations }\end{array}$} & $\begin{array}{l}\text { (1) Independent } \\
\text { learning }\end{array}$ & $\begin{array}{l}\text { High engagement, High self-esteem, } \\
\text { Very happy, Very interested, Very } \\
\text { relaxing }\end{array}$ & Low anxiety \\
\hline & $\begin{array}{l}\text { (2) Collaborative } \\
\text { learning }\end{array}$ & $\begin{array}{l}\text { High engagement, Very happy, Very } \\
\text { interested, Very relaxing }\end{array}$ & Low anxiety \\
\hline & (3) Sense of pride & $\begin{array}{l}\text { High self-esteem, Very comfortable, } \\
\text { Very happy, High motivation, Very } \\
\text { relaxing }\end{array}$ & Low anxiety \\
\hline & $\begin{array}{l}\text { (4) Environmental } \\
\text { considerations }\end{array}$ & Very comfortable & \\
\hline \multirow[t]{4}{*}{$\begin{array}{l}\text { Process of writing } \\
\text { related situations }\end{array}$} & $\begin{array}{l}\text { (5) Finding } \\
\text { information }\end{array}$ & $\begin{array}{l}\text { High concentration, Very happy, Very } \\
\text { interested, High motivation }\end{array}$ & Low anxiety \\
\hline & $\begin{array}{l}\text { (6) Analyzing the } \\
\text { data }\end{array}$ & High concentration, High motivation & Low anxiety \\
\hline & (7) Amount of work & High concentration & \\
\hline & $\begin{array}{l}\text { (8) Content of the } \\
\text { activity }\end{array}$ & High self-esteem, Very happy & \\
\hline \multirow[t]{2}{*}{$\begin{array}{l}\text { Technology related } \\
\text { situations }\end{array}$} & $\begin{array}{l}\text { (9) The use of } \\
\text { phone }\end{array}$ & $\begin{array}{l}\text { Very comfortable, Very happy, Very } \\
\text { interested, High motivation }\end{array}$ & \\
\hline & $\begin{array}{l}\text { (10) The use of QR } \\
\text { codes }\end{array}$ & $\begin{array}{l}\text { High concentration, Very happy, Very } \\
\text { interested, High motivation, Very } \\
\text { relaxing }\end{array}$ & Low anxiety \\
\hline $\begin{array}{l}\text { Teacher related } \\
\text { situations }\end{array}$ & $\begin{array}{l}\text { (11) Method of } \\
\text { teaching } \\
\text { (12) Personality }\end{array}$ & $\begin{array}{l}\text { High engagement, Very interested, } \\
\text { High motivation } \\
\text { Very relaxing }\end{array}$ & \\
\hline
\end{tabular}

In the third category, technology related situations cover the use of phone and QR codes in the writing class. For the use of phone, it includes very comfortable (i.e., I feel very comfortable when I can get the information via my phone), very happy (i.e., I feel very happy when I use my phone to find something), very interested (i.e., I feel very interested when I use my phone as a learning tool), and high motivation (i.e., I feel highly motivated when I read the sentence from my phone). For the use of QR codes, five ALLAs were included such as high concentration (for example, I have high concentration when I found that QR codes are useful), very happy (for example, I feel very happy when it's easy to read and reply), very interested (for example, I feel very interested when the activity in class uses new way like QR code), high motivation (for example, I have high motivation when I saw that a lot of QR codes were in the room), and very relaxing (for example, I feel very relax when I am not listening to lecture but instead playing with the QR codes). 
Teacher related situations comprise the fourth category. It includes the teacher's teaching method, which provokes the following ALLAs: high engagement (for instance, I am engaged actively when the teacher uses a new way to teach), very interested (for instance, I feel very interested when I walk around the classroom instead of lecture), and high motivation (for instance, I have high motivation when there is a new way of learning. Beside teaching method is the teacher's personality, which can make the students feel very relax, for example, I feel very relax when the teacher is friendly.

Based on thematic analysis above, it suggests the interplay of affective language learning variables in the classroom. The findings support my earlier argument that integration of QR code, as an example of technology, in writing activities in graduate EFL classroom could result to favorable language attributes that could help increase other variables, and that it has positive effect on language performance. Further findings have shown that except for teacher related situations, all other categories have decreased anxiety.

\section{DISCUSSION}

Using QR codes in writing increases learners' affective state, specifically lesser known variables such as happiness, interest, comfortableness, relaxation, concentration and engagement. In the results, answers for questions 1 and 2 complement the findings in previous literature. Except for anxiety, eight affective variables after the QR code activity received positive ratings from 5.42 to 6.26 . The increase of affect in technology-driven language activities, for example, motivation, has been reported by (Durak et al., 2016; Midraj, 2003; Rivers, 2009), among others. Identifying specific situations during the activity is important to explain how QR code activities have driven higher positive affect of graduate students in language learning. Insights of the students indicated that game-based in-class writing activities promote independent learning, collaborative learning, sense of pride, and comfortableness of learning environment. It appears that when students took control on some parts of the learning process, they became actively engaged, gained self-esteem, got interested, felt happier and relaxed. Moreover, when students were able to do the activity (e.g., scanning QR codes), they felt sense of pride - being able to do something on their own.

There is an observed interplay of positive affect as students were allowed to work freely with others during the activity. Despite the technologies issues such as those reported by (Rivers, 2009), having moving writing activities while using their phones at hand seem to provide a comfortable learning environment. As the graduate students are millennials, the use 
of technology seemed to show an impact that helps cultivate positive affect in language learning.

Anxiety remains an issue even for graduate students (Vo et al., 2017). In the codes provided in Table 4, it shows that the teacher provokes language anxiety. Although the teacher's personality is labelled as very relaxing and the method of teaching have encouraged high levels of interest, engagement and motivation among the students, the mere presence of the teacher is anxiety-provoking. Future studies may explore the role of teacher-student distance in the classroom in decreasing the level of anxiety.

\section{CONCLUSIONS}

By doing classroom action research, not only the affective language learning attributes of QR code activity in writing among graduate EFL students were known but also it provided more insights on the interplay of affect in specific situations in a writing task. Language teachers of graduate EFL courses may consider incorporating technology-driven activities to induce higher levels of affect necessary for language learning.

Since this study aimed to help the teacher-researcher and make the results known to other language teachers, the following implications were drawn for teaching graduate students: (1) promoting independent learning in teaching writing, (2) encouraging collaborative writing activities, (3) cultivating self-esteem through 'can-do' writing activities, (4) improving classroom learning conditions, for example, comfortableness of the learning environment, (5) incorporating 'moving' activities in teaching writing, (6) giving more time when reading or analyzing text, (7) delimiting the amount of work - 'not too much but not too little', (8) providing topic that students can write something about it, (9) using technologies in writing, e.g., phones and QR codes, (10) being friendly to decrease language anxiety in class, and (11) improving teaching through classroom action research.

To prevent unnecessary disruptions in using QR codes in writing activities, two steps could be considered. First, ask the students to get their phones ready before class by making sure that the battery is charged sufficiently. Secondly, let the students download a QR code reader compatible with their phone's operating system.

\section{REFERENCES}

Al-Khalifa, H. S. (2011). An M-learning System Based on Mobile Phones and Quick Response Codes. Journal of Computer Science, 7(3), 427-430.

Arnold, J., \& Brown, H. D. (1999). A Map of The Terrain. Affect in Language Learning, 221. 
Durak, G., Ozkeskin, E., \& Ataiza, M. (2016). QR Codes in Education and Communication. Turkish Online Journal of Distance Education - TOJDE, 17(2), 42-58.

Gömleksiz, M. N. (2010). An evaluation of students' attitudes toward English language learning in terms of several variables. Procedia - Social and Behavioral Sciences, 9, 913-918. https://doi.org/10.1016/j.sbspro.2010.12.258

Henter, R. (2014). Affective Factors Involved in Learning a Foreign Language. Procedia Social and Behavioral Sciences, 127, 373-378. https://doi.org/10.1016/j.sbspro.2014.03.274

Horwitz, E. (2001). Language Anxiety and Achievement. Annual Review of Applied Linguistics, 21(1), 112-126.

Horwitz, E. K., Horwitz, M. B., \& Cope, J. (1986). Foreign Language Classroom Anxiety. The Modern Language Journal, 70(2), 125-132.

Kalra, R., \& Siribud, S. (2020). Public speaking anxiety in the Thai EFL context. LEARN Journal: Language Education and Acquisition Research Network. Retrieved from https://www.scopus.com/inward/record.uri?eid=2-s2.085079679011\&partnerID=40\&md5=7b10a45715eeadd4b2e8ae7b5436e71f

Lee, J. H., \& Lo, Y. Y. (2017). An exploratory study on the relationships between attitudes toward classroom language choice, motivation, and proficiency of EFL learners. System, 67, 121-131. https://doi.org/10.1016/j.system.2017.04.017

MacIntyre, P. D., \& Gardner, R. C. (1989). Anxiety and Second-Language Learning: Toward a Theoretical Clarification*. Language Learning, 39(2), 251-275. https://doi.org/10.1111/j.1467-1770.1989.tb00423.x

McCabe, M., \& Tedesco, S. (2012). Using QR Codes and Mobile Devices to Foster an Inclusive Learning Environment for Mathematics Education. International Journal of Technology and Inclusive Education, 1(1), 3743.https://doi.org/10.20533/ijtie.2047.0533.2012.0006

Midraj, S. (2003). Affective Factors and ESL Learning. Proceedings of the 5th and 6th Current Trends in English Language Testing, 19-32.

Rivers, D. J. (2009). Utilizing the Quick Response (QR) Code within a Japanese EFL Environment. Jaltcalljournal, 5(2), 15-28.

Saville-Troike, M. (2006). Introducing Second Language Acquisition. Cambridge: Cambridge University Press.

Situmoranga, R., Siangb, J. L., Ibrahimc, N., \& Lagunsiangd, J. (2019). Development of Collaborative Learning Materials Based on QR Code to Facilitate Learning. Development, $8(6)$. 
Vo, T. D., Wilang, J., \& Samoilova, V. (2017). Debilitating Effects of Anxiety on Engineering Students' Language Performances. The International Conference on Innovation in Education.

Yang, Q.-F., Chang, S.-C., Hwang, G.-J., \& Zou, D. (2020). Balancing cognitive complexity and gaming level: Effects of a cognitive complexity-based competition game on EFL students' English vocabulary learning performance, anxiety and behaviors. Computers and Education. https://doi.org/10.1016/j.compedu.2020.103808 